\title{
Herding Behavior of Ghana Stock Market Participants: \\ A Daily Analysis
}

\author{
Isaac Boadi \\ University of Professional Studies \\ James Ntiamoah Doku \\ University of Professional Studies \\ Daniel Osarfo \\ University of Ghana \\ Thompson Aneyire Kubaje \\ University of Professional Studies \\ Samuel Mensah \\ University of Professional Studies \\ Peter Ackah \\ University of Professional Studies \\ Siddique Abdul-Samad \\ University of Professional Studies
}

\begin{abstract}
This study investigates the herding behavior of Ghana stock market participants and its impact on stock returns. Using panel data of 38 equities listed on the Ghana stock market, the data spans from 2011 to 2019. Fixed effect model was used for all estimations. Overall, the study results failed to indicate evidence of herding behavior in the Ghana stock market. This result further indicates that at low levels, the market participants herd but at higher levels, there is the absence of herding behavior. In bull market conditions, market participants act in unison only at high levels. The result validates the assumption of the rational asset pricing model.
\end{abstract}

Keywords: herd behavior, Ghana stock exchange, fixed effect model 


\section{INTRODUCTION}

Not until the 1980s when a comparatively new idea, behavioral finance, emerged in the fields of economics and finance, researchers and academicians have assumed that efficient market hypothesis $(\mathrm{EMH})$ dominated the functioning of equity markets (Fama, 1990). The efficient market hypothesis (EMH) is anchored on the stance that investors behave rationally in the financial market. Behavioral finance, on the other hand, does not only focus on the psychological aspect of investors in making financial decisions but also explains the irrationality of investors in their investment decision-making. Herding refers to the situation wherein rational people start behaving irrationally by imitating the judgments of others while making decisions (Kumar \& Goyal, 2018). It is considered as one of the various types of behavioral biases of investors.

The study focuses on Ghana and its contributions are informed by some factors. First, Kumar \& Goyal (2015) study on rationality and behavioral biases in investment decision making, suggested that future research studies herding behaviors of investors could concentrate on emerging stock markets. The basis for this suggestion is premised on the fact that after globalization, emerging economies have higher growth potentials and investors (institutional and individuals) are more inclined to invest in the share market. Kumar \& Goyal (2015) suggestion is supported by the empirical study of Tan et al. (2008) who concluded that herding behavior in emerging markets has several implications on stock risk and return characteristics. As shown in Table 1, while evidence of the existence of herding has received extensive attention in developed economies like the USA, Europe and Asia, surprisingly evidence is rare in emerging markets including Ghana Stock markets. Ghana is expected to become the fastest-growing economy in Sub-Saharan Africa with a GDP growth rate of $8.8 \%$ in 2019 (IMF, 2019). A relatively well-developed country is ranked as the fourth most peaceful in Sub-Saharan Africa and $44^{\text {th }}$ in the world (The Institute for Economics \& Peace, 2019). Ghana is considered as a market-based economy with relatively few policy barriers to trade and investment in comparison with other countries in the region. After a dip in 2018 as shown in Figure 1, the stock market has started experiencing a bullish trend in recent times. Since every investor is primarily interested in the safety of their investments, these credentials put the country on the spotlight for a meaningful study to be carried out. Thus, the suggestion by Kumar \& Goyal (2015) merits an extensive examination, especially for stock market participants operating in Ghana which has been neglected largely in the existing literature. Second, this work is singular in the sense that it attempts to examine herding behavior in the Ghana stock not only in the overall market conditions but also under different market conditions (Bull and Bear) with more recent data. Ghana stock exchange transformation started in 2011 with the introduction of Ghana Stock Exchange (GSE) Composite Index. The data points are carefully selected because of its relevance in the Ghana stock exchange transformation in recent years. It is to help capture the herding behavior of market participants after the global financial meltdown. Furthermore, empirical studies have shown that stock market participants in emerging markets are more likely to demonstrate herding behavior because of information failure (Javaira \& Hassan, 2015). Ferruz \& Vargas (2007) indicated that investors usually change their investment plans and decisions in the financial market based on other investors' decisions and this may cause a deviation from the fundamentals of stock market prices. Herding behavior may result in inaccurate earnings estimates (Olsen, 1996). This is relatively a common phenomenon in the Sub-Saharan countries particularly Ghana. Finally, considering the level of understanding of herding and their impact on stock market performance, the present study could contribute to more reliable valuation and forecasting while making investment choices.

The study sections are organized as follows: Section 2 focuses on the literature review and hypothesis development. Data and methodology are discussed in section 3. Results of the study are presented in the next section. Section 5 concludes the study. 


\section{FIGURE 1}

\section{GSE RETURNS}

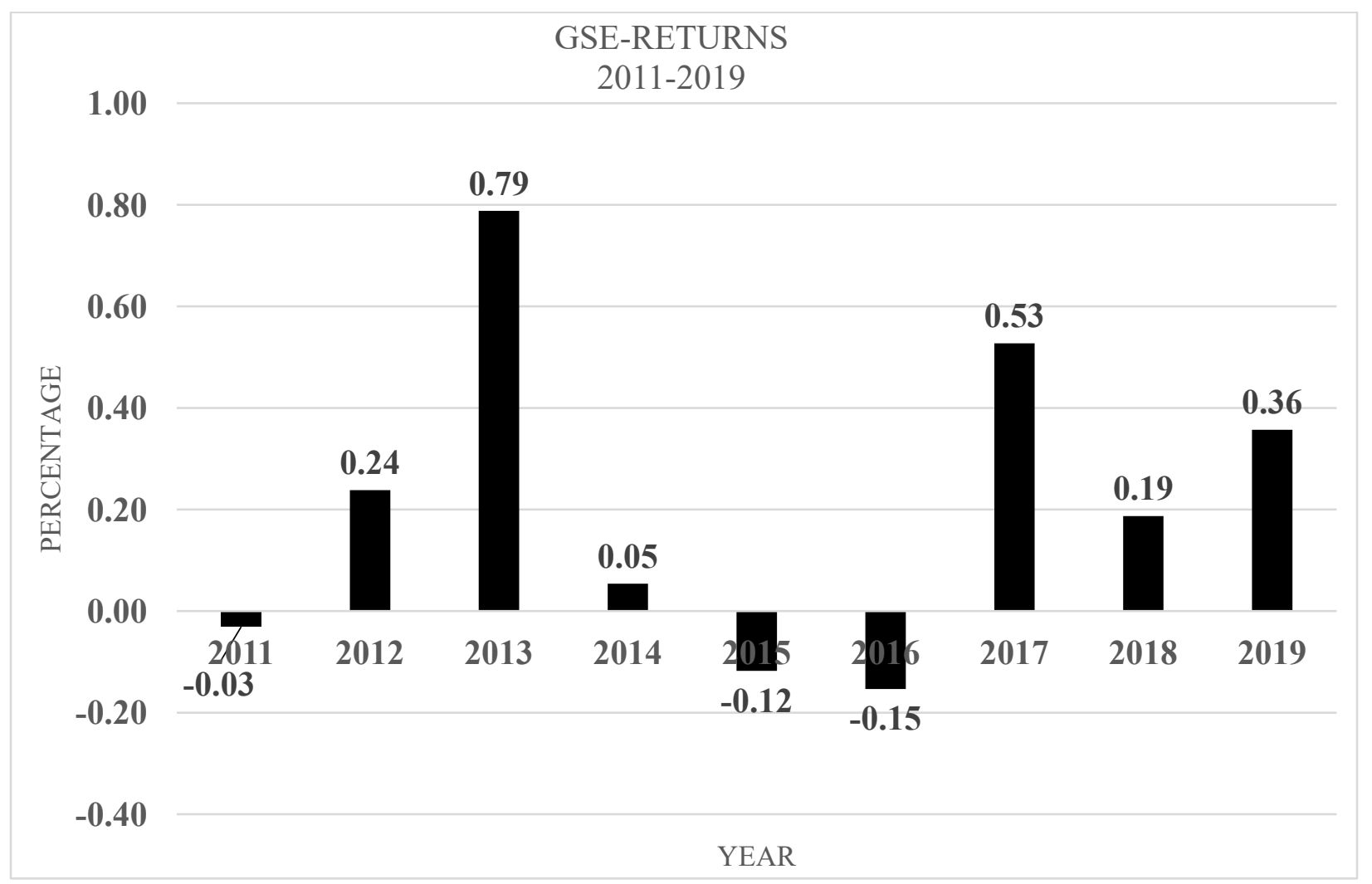

Source: Author's compilation (2021)

\section{THEORY AND LITERATURE REVIEW}

\section{Theoretical Perspectives}

The present study is situated into four streams of theories namely the information cascade hypothesis, the reputation hypothesis, regulatory arbitrage hypothesis and Information-driven-hypothesis. The relevance of these theories remains unsettled. Information cascade hypothesis simply describes a situation in which a number of people make the same decision in a logical order (Banerjee, 1992). Second, the reputation hypothesis initially developed by Scharfstein \& Stein (1990) posits that anytime investors act differently from the crowd they face reputational risk. Third, the Regulatory arbitrage hypothesis states that firms or institutions capitalize on flaws and inconsistencies in regulatory systems in an attempt to circumvent unfavorable regulation. This is often possible when loopholes are obvious and costs associated with circumventing the regulation are not stringent and harsh enough. Finally, the information-driven hypothesis stipulates that informed investors may take certain strategic decisions that may reveal useful information to uninformed investors resulting in the need to follow (Froot et al., 1992). While the relevance of these theories remains unsettled, the present study would attempt to validate or invalidate these theories.

\section{Empirics on Herding Behaviour}

The empirical support for herd behavior is mixed. Table 1 illustrates a summary of empirical evidence of herding behaviors in a single market setting. While Panel A demonstrates the presence of herding, Panel $\mathrm{B}$ discusses studies on the non-existence of herding in a single market setting. From the related studies presented and reviewed in Table 1, the literature provided solid observable evidence about the relevance of herding in investment decisions. With respect to the non-existence of herding behaviour among investors, 
Christie \& Huang (1995) find no evidence of herding in the US. In Pakistan, Javaira \& Hassan (2015) invalidate herd behavior. Chang et al. (2000) conclude that market participants in the US and Hong Kong do not herd. Gleason et al. (2004) support the conclusion that investors do not herd during periods of extreme market movements. In China, Demirer \& Kutan (2006) distinguished between the Shanghai and Shenzhen stock exchanges at the sector-level and established that herd formation does not exist in Chinese markets. Economou et al. (2011) provide comprehensive evidence testing for the existence of herding effects in the Portuguese, Italian, Spanish and Greek market from 1998-2008. While herding is found to be present in Greek and Italian markets, the opposite and mixed results are found for Spanish and Portuguese markets respectively. In Dhaka exchange market, Sarkar \& Ahsan (2013) empirical work finds no support to suggest herding. Several other studies however, have confirmed pro-herding behaviours. For instance, Galariotis et al. (2015) conclude that US investors tend to herd during days when important macro data are released. Cajueiro \& Tabak (2009) find evidence of herding behaviour in Japan's stock market during bearish periods. Bhaduri \& Mahapatra (2013) find that herding exists in the Indian stock market, but it occurs in certain years than others. Using nine markets as sample size, Ornelas \& Alemanni (2008) results confirm herding behaviour. A study using some selected countries in the Gulf countries under extreme market conditions for all markets confirmed herding except Qatar which herds only under high volatility conditions (Balcilar et al., 2013). Mobarek et al. (2014) identify herding in Greece during the Eurozone crisis. Zhou \& Anderson (2011) findings suggest herding behaviour in the down market and extreme market (high quantiles) conditions. Philipas et al. (2013) find evidence of herding behaviour during down market conditions. Interestingly, few studies support mixed results in the same markets regarding herding. For instance, while herding exists within Shanghai and Shenzhen A-share markets using the least-square model, B-share markets do not exhibit herding (Chiang et al., 2010).

Findings from these selected related studies, revealed some research gaps and therefore constitute a point of departure for this paper. First, the theoretical and related studies reviewed on herding suggest that in equity markets herding may occur when there is a lack of information regarding financial assets. This means that the release of both micro and macro-economic news significantly influences investors' behaviour. Stated differently, information asymmetry among investors often results in herding ( Javaira \& Hassan, 2015). This phenomenon is relatively common in most of the Sub-Saharan stock markets, particularly Ghana. Hence the focus on Ghana stock market. Second, different market conditions and estimating models not largely considered by previous studies compelled the present study. Related empirical studies (Chiang et al., 2010; Xuan 2017) examined various markets dynamics such as quadratic relationship, asymmetry in bullish and bearish periods, irregular market return, swings in trading and asymmetric market volatility. The present study extends the existing literature as follows: (i) data is decomposed into six sectors and herding tested under these sectors, (ii) herding behaviour of Ghanaian investors when important fundamental information and macro data are released, (iii) herding behaviour is tested mainly under post-global financial crisis, (iv) estimate the impact of herding on stock returns. Third, the related literature reviewed revealed rather mixed findings from a number of markets. As shown in Table 1 , while some investigations confirmed the presence of herding in some markets, other findings reported the absence of herding. The inconclusive reports make the focus on Ghana relevant. This is because several of these studies were conducted using the developed economies. For instance, in the US, Europe and Asia where the impact may differ. In the Sub-Saharan countries like Ghana, such studies are rare. Finally, the empirical work of Demirer et al. (2007) concludes that dispersion in African markets follows a parabolic path. Therefore, validating such positions using the Ghana stock market will further help contribute to existing literature. The inconclusive results reported by prior studies, add to the call to fully examine the herding behaviour of investors under extreme market conditions using Ghana stock market participants as a reference point. The current study, therefore, hypothesizes as follows:

\section{$\boldsymbol{H}_{1}:$ Ghana stock market exhibits herding behaviour due to asymmetry of information among Investors.}

\section{$\boldsymbol{H}_{2}:$ Herding impacts positively on stock returns.}




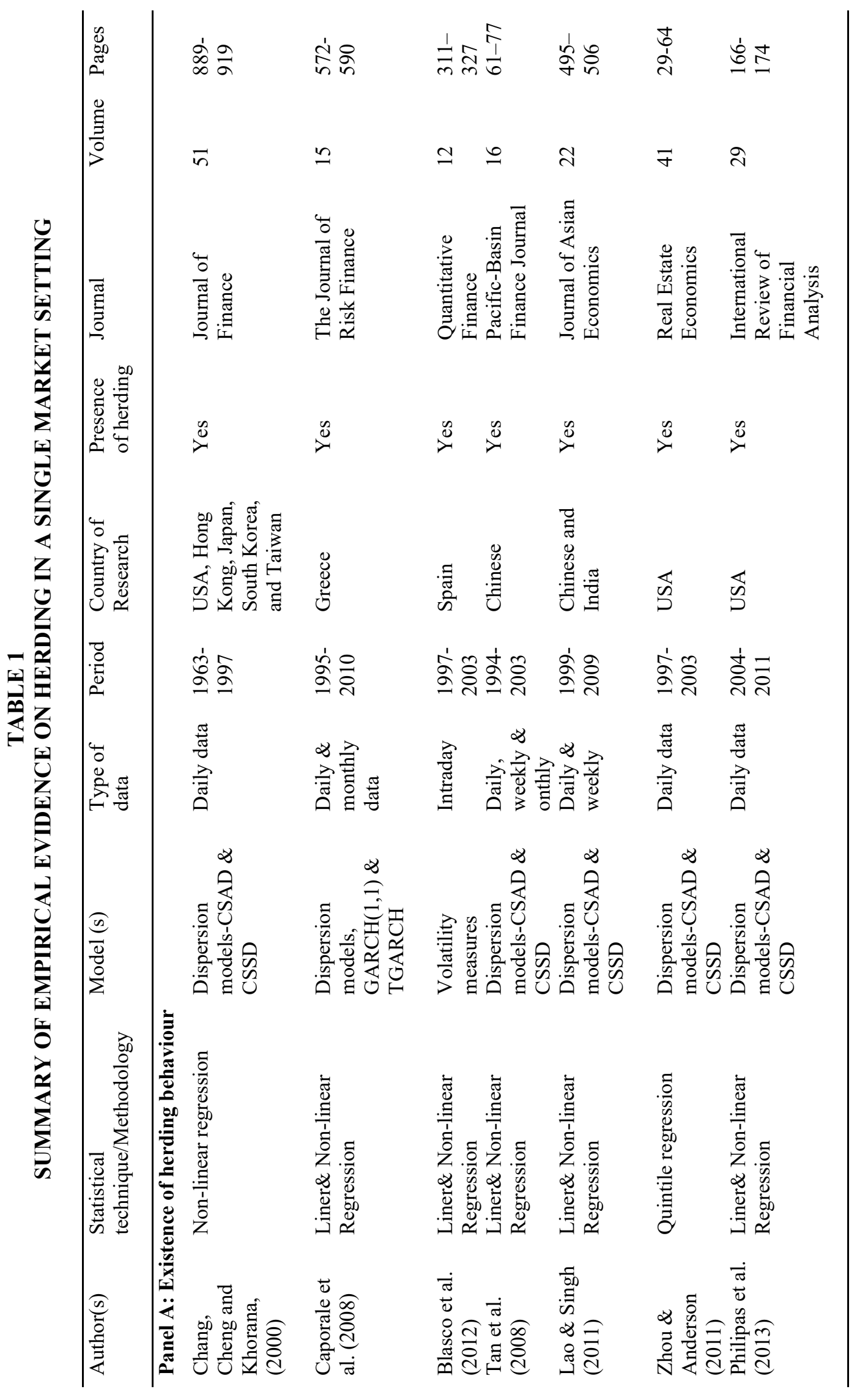

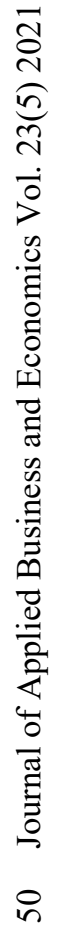




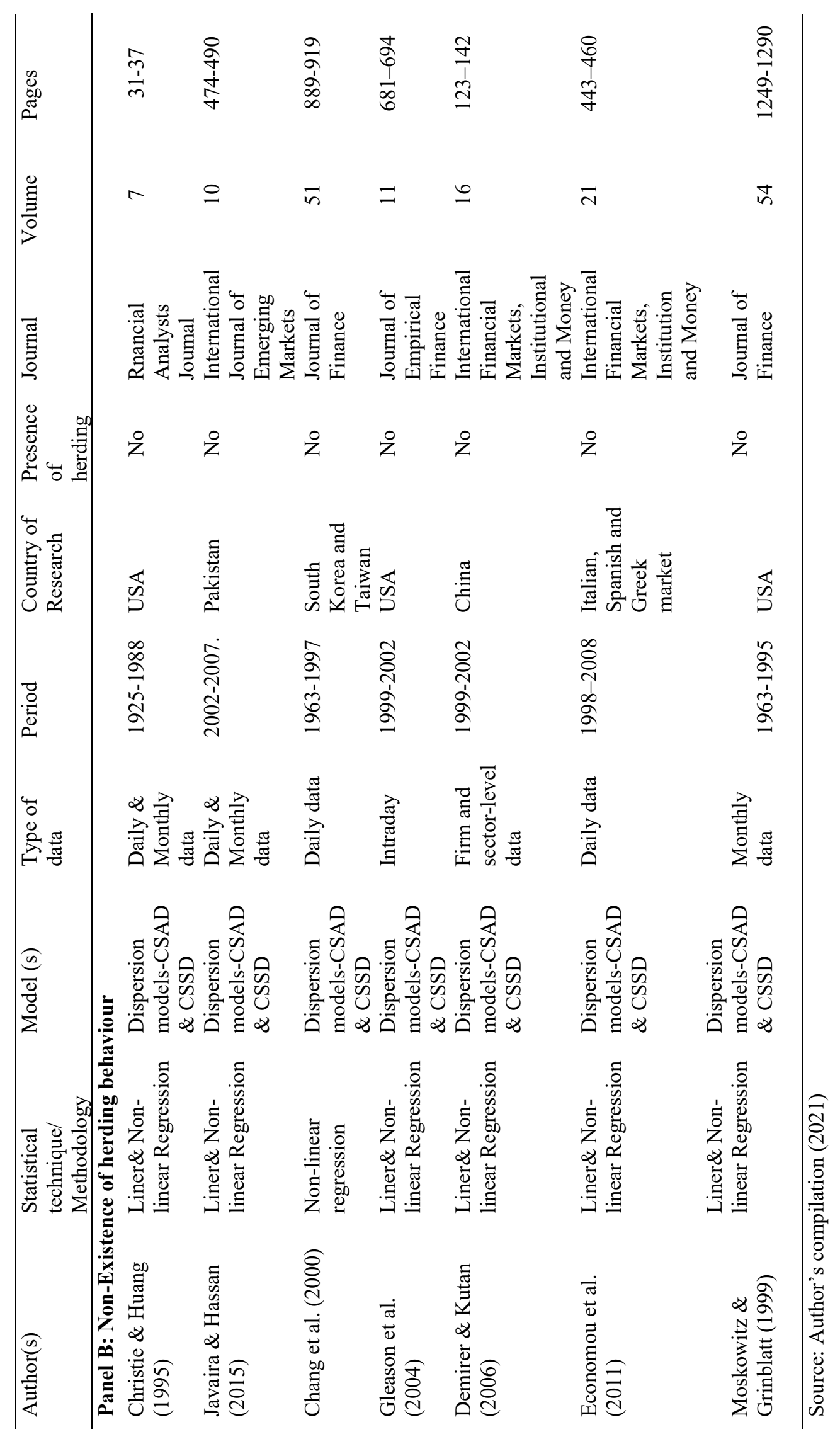

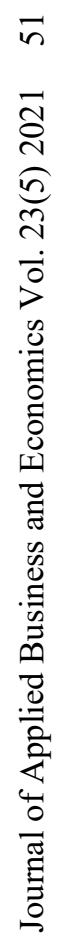




\section{DATA AND METHODOLOGY}

The present study investigates the presence of herding under different market conditions and estimates its impact on stock returns. This is done by employing the following two measures of herding, namely: cross-sectional standard deviation (CSSD) and cross-sectional absolute deviation (CSAD). These measures are previously used by Christie \& Huang (1995) and Chang et al. (2000) respectively. Whereas CSSD estimates the average closeness of individual asset returns to the realized market average, CSAD estimates the relationship between the overall market returns and the level of equity returns dispersion in a quadratic regression specification. Gleason et al. (2004) combined both CSSD and CSAD to capture herding in overall market conditions. Due to the extreme variations in market conditions, these methodologies concentrate on the cross-sectional correlation dispersion in stock returns. Javaira \& Hassan (2015) posit that owing to the presence of information asymmetry, emerging markets are more likely to demonstrate herding behaviour. This study used the fixed effect model for all estimations. The choice for a fixed effect model stems from the fact that using data from different industries or sectors with varying scales of operation generate some heterogeneity in terms of different managerial skills, access to technology, capitalization, and regulation. This may exhibit some appreciable level of inertia and may be deemed timeinvariant. The fixed effect model eliminates those time-invariant individual heterogeneities using appropriate transformations and, thus, helps to ascertain the net effect predictors have on outcomes.

\section{Data Description}

The study uses daily data comprising closing prices and trading volumes of 38 equities listed on the Ghana stock market. The daily data spans from July 7, 2011, to April 31, 2019. The justification for the data span are as follows: First, this was the period when Ghana stock exchange (GSE) replaced GSE ALL SHARE INDEX with GSE COMPOSITE INDEX. Again, the selected data span is to help capture the herding behaviour of market participants after the global financial meltdown. The study includes 66,372 observations of daily returns and trading volumes. In selecting the equities for the study, the authors controlled and applied the following restrictions: (1) all selected firms have been continuously trading during the sample period and are representative of the Ghanaian market, (2) delisted equities or firms are considered and excluded, (3) equities without the required data are eliminated, (4) financial equities merged and acquired are considered, (5) equities which names were changed as result of rebranding or for strategic reasons are controlled and considered, (6) differences in accounting practices, reporting periods and types of financial ratios often used by these equities compelled the author to group firms into six (6) sectors .i.e. Consumer Discretionary, Energy, Financial, Healthcare, Industry and Information Technology, (7) sectors that had only one equity are dropped from the analysis because they could not be estimated with panel regression methods, (8) equities with missing observations are considered and dropped. The consideration for the above-mentioned restrictions made the number of equities unbalanced. An average of 38 equities fulfilled the sample requirements. The historical data is obtained from the web sites www.annualreportsghana and www.worldbank.org. Table 2 shows the performance indicators for the sectors. 


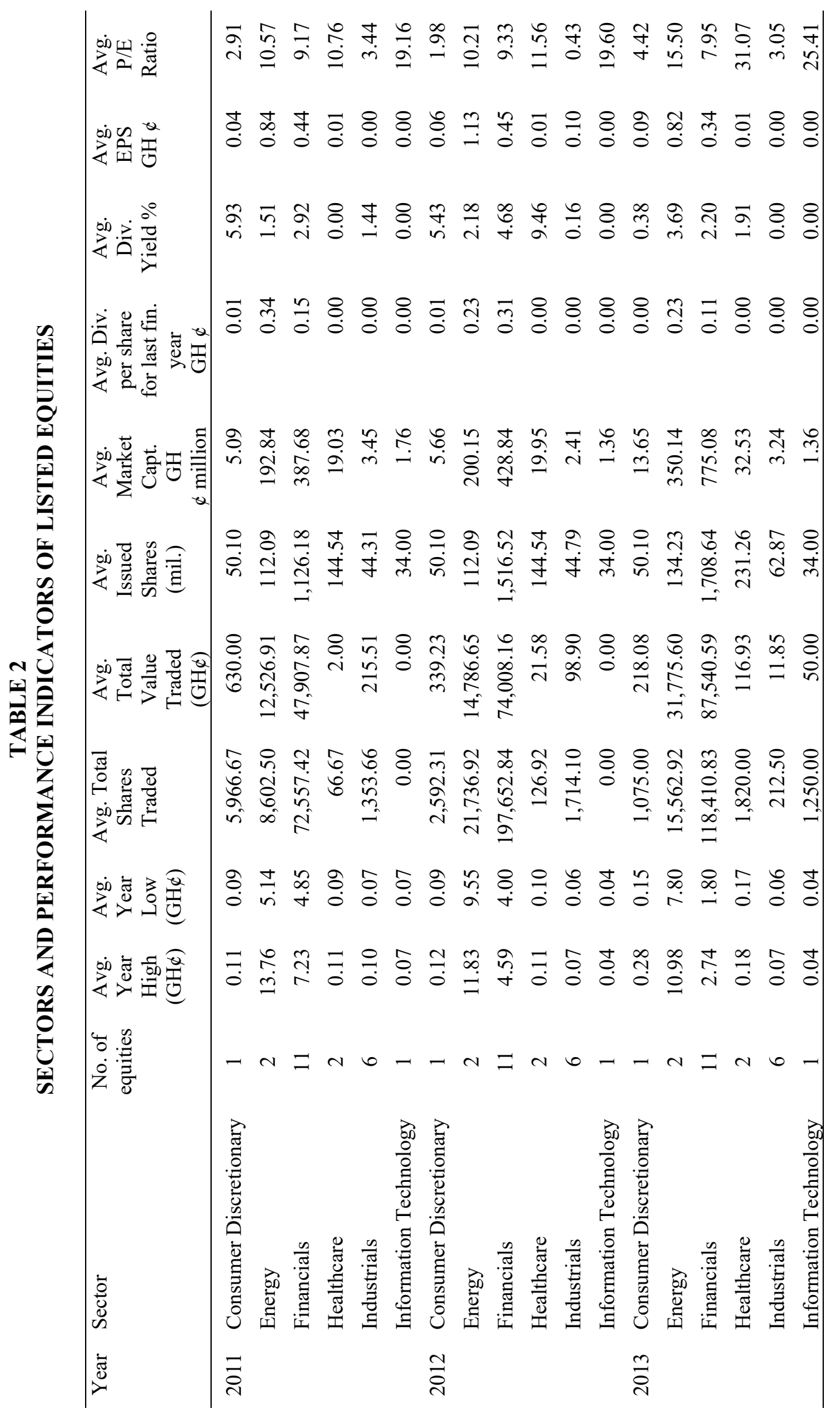

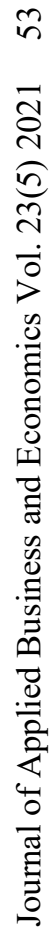




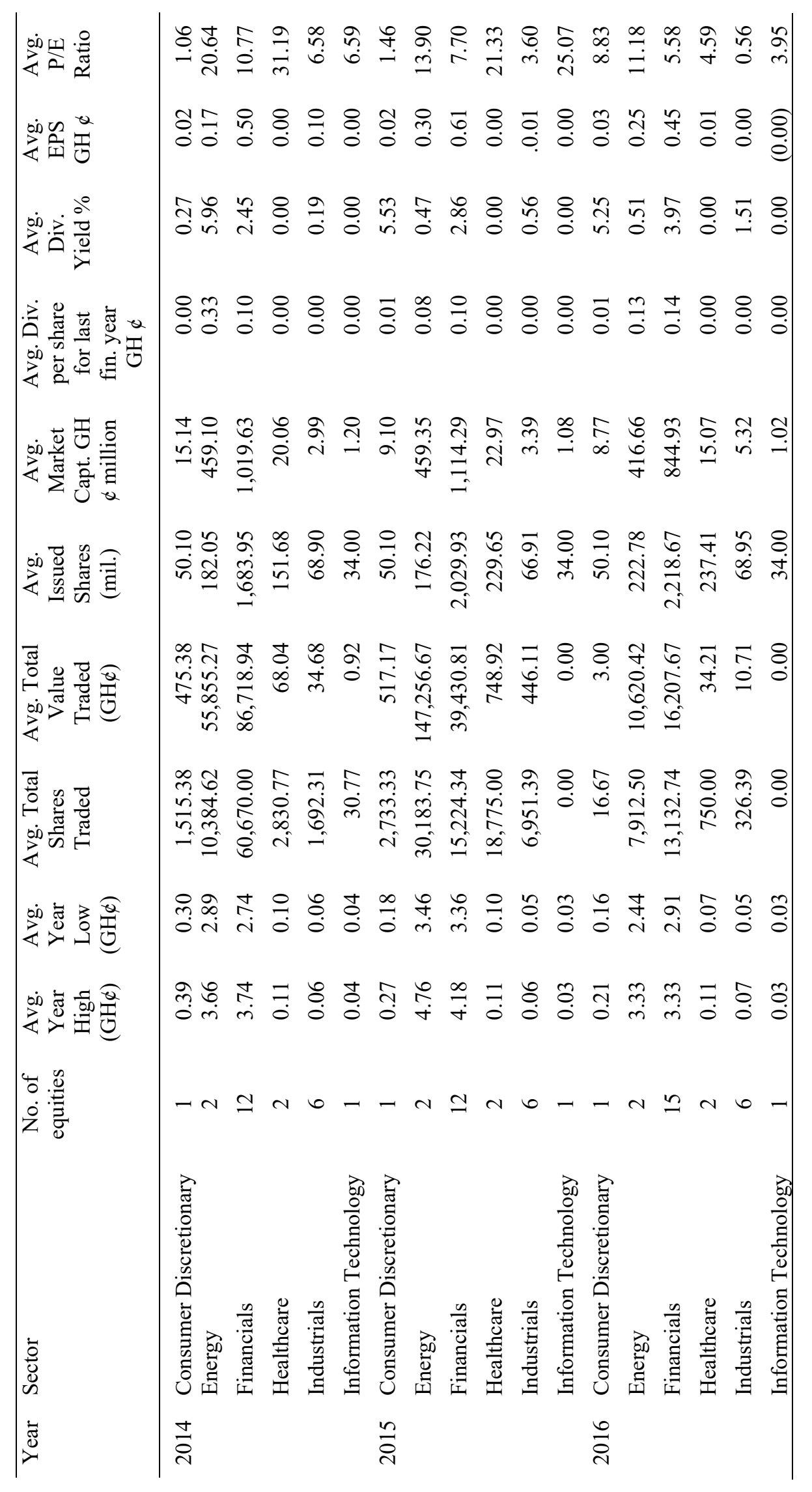




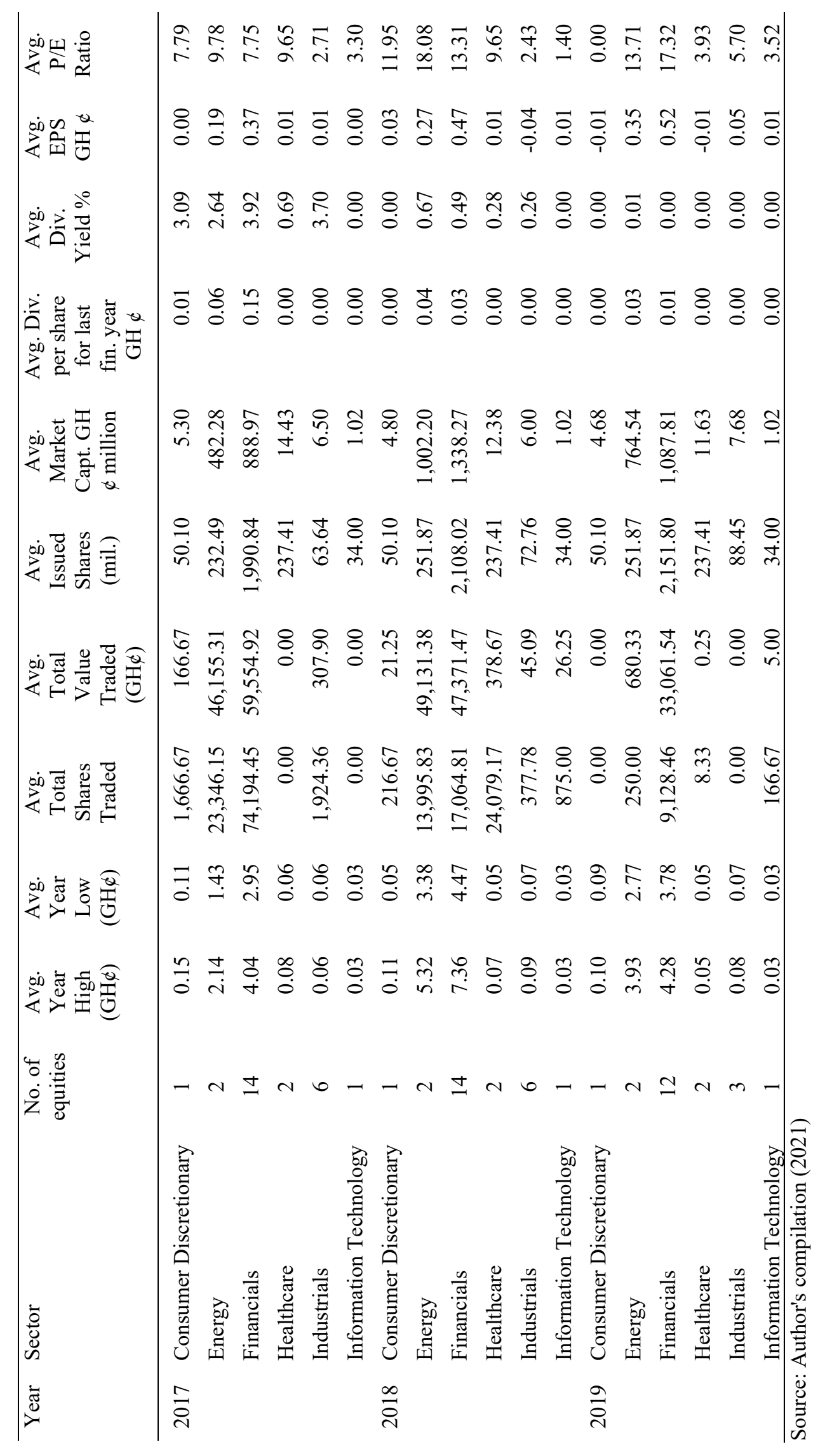




\section{Stock Return Estimations}

The observed stock return for individual firm shares is calculated as:

$R_{i, t}=\ln \left[\frac{P_{t}}{P_{t-1}}\right] \times 100$

where $R_{i, t}$ represents the observed stock return of firm $i$ at time $t, P_{t}$ and $P_{t-1}$ are the closing and beginning prices of the individual stock at time $t$ and $t-1$ respectively. $\left(N_{\text {returns }}\right) R_{m, t}$ represents the cross-sectional average stock of $\mathrm{N}$ returns is estimated by taking the average of all individual stock returns at time $t$ :

$$
R_{m, t} \frac{\sum R_{i, t}}{N}
$$

where $R_{m, t}$ is the observed stock return of firm $\mathrm{i}$ at time $t$, and $\mathrm{N}$ is the number of firms included in the sample.

\section{Methodology}

As indicated, two methods used to identify herd behaviour are estimated and discussed as follows: First, Christie and Huang (1995) estimate CSSD as:

$\operatorname{CSSD}_{t}=\sqrt{\frac{\sum_{i=1}^{N}\left(R_{i, t}-R_{m, t}\right)}{N-1}}$

where $N$ indicates the number of firms in the portfolio, $R_{i, t}$ is the realized stock return of firm $i$ at timet, $R_{m, t}$ is the cross-sectional average stock of $N$ returns in the portfolio at timet. Herding behaviour found in market stress sessions is characterized by deviation from the traditional asset pricing model concerning the behaviour of the CSSD of returns. Whereas the rational asset pricing model results in increased dispersion, the presence of herding results in proportionately lower dispersion in periods of large market movements. The present study estimates the following empirical design suggested by Christie \& Huang (1995):

$\operatorname{CSSD}_{t}=\alpha+\beta_{1}^{U} D_{t}^{U}+\beta_{2}^{L} D_{t}^{L}+\varepsilon_{t}$

where $C S S D_{t}$ represents the return dispersion at timet. At the extreme upper and the extreme lower tails of the return distribution, $D^{U}=1$ and $D_{t}^{L}=1$ respectively. This is relevant in situations where the return on the aggregate market portfolio for the time period $t$ falls within this range, and 0 otherwise. This, therefore, indicates that while a negative and statistically significant $\beta_{1}$ and $\beta_{2}$ coefficient suggests herd formation by market participants, significantly positive coefficients $\beta_{1}$ and $\beta_{2}$ establish the prediction of rational asset pricing model. Second, Chang et al. (2000) identify herding by using a cross-sectional absolute deviation (CSAD). The relevance of CSAD is because the Christie \& Huang (1995) model lacks a clear market stress definition. CSAD is denoted as follows:

$\operatorname{CSAD}_{t}=\frac{1}{N} \sum_{i=1}^{N}\left|R_{i, t}-R_{m, t}\right|$

According to Chang et al. (2000), the CSAD is arrived at because of the general non-linear relationship between $C S A D_{t}$ and $R_{m, t}$. This relationship is therefore modelled as follows:

$\operatorname{CSAD}_{t}=\alpha+\gamma_{1}\left|R_{m, t}\right|+\gamma_{2} R_{m, t}^{2}+\varepsilon_{t}$

While a negative and significant non-linear coefficient of $\gamma_{2}$ suggests that herding behavior exists in the market, a statistically significant positive $\gamma_{2}$ confirms the absence of herding (Chang et al., 2000). Third, 
Gleason et al. (2004) indicate that a quadratic relationship can be observed for CSSD if herding is present in market stress situations. Specifically, Gleason et al. (2004) interchange the dependent variables in Equations (2) and (4) and tested these two models as:

$$
\begin{aligned}
& \operatorname{CSAD}_{t}=\alpha+\beta_{1}^{U} D_{t}^{U}+\beta_{2}^{L} D_{t}^{L}+\varepsilon_{t} \\
& \operatorname{CSSD}_{t}=\alpha+\gamma_{1}\left|R_{m, t}\right|+\gamma_{2} R_{m, t}^{2}+\varepsilon_{t}
\end{aligned}
$$

Importantly, in more advanced market conditions, the rate of increase in dispersion with regards to combined market returns is higher than where the market slows down. Herding is therefore measured independently for positive and negative market returns to examine the imbalance in bullish and bearish movements. Categorically, the equation is stated as:

$$
\begin{aligned}
& C S A D_{t}^{U P}=\alpha+\gamma_{t}^{U P}\left|R_{m, t}^{U P}\right|+\gamma_{2}^{U P}\left(R_{m, t}^{U P}\right)^{2}+\varepsilon_{t}, \quad \text { if } R_{m, t}>0 \\
& C S A D_{t}^{\text {Down }}=\alpha+\gamma_{t}^{\text {Down }}\left|R_{m, t}^{\text {Down }}\right|+\gamma_{2}^{\text {Down }}\left(R_{m, t}^{\text {Down }}\right)^{2}+\varepsilon_{t}, \quad \text { if } R_{m, t}<0
\end{aligned}
$$

where $C S A D$ at time $t$ for both swings (up and down) times are represented by $C S A D_{t}^{U p}$ and $C S A D_{t}^{D o w n}$ respectively. $R_{m, t}^{U p}$ and $R_{m, t}^{D o w n}$ proxy the equal-weighted portfolio returns in bullish and bearish market periods respectively at timet. The squared value of the equal-weighted portfolio to examine the quadratic relationship in market returns when the market swings (up and down) are represented by $\left(R_{m, t}^{U p}\right)^{2}$ and $\left[\left(R_{m, t}^{\text {Down }}\right)^{2}\right]$.

In testing the robustness of the analysis, the study includes both fundamental information and macroeconomic fundamental variables which have successfully been predicted to have variations in future stock returns (Swanson et al., 2003; Boadi, 2018). These characteristics potentially influence asset price and ultimately herding tendencies. This is expressed as follows:

$$
\begin{aligned}
& \operatorname{CSSD}_{t}=\alpha+\gamma_{1}\left|R_{m, t}\right|+\gamma_{2} R_{m, t}^{2}+\beta_{1}\left(X_{t}\right)+\beta_{2}\left(Z_{t}\right)+\varepsilon_{t} \\
& \operatorname{CSAD}_{t}=\alpha+\gamma_{1}\left|R_{m, t}\right|+\gamma_{2} R_{m, t}^{2}+\beta_{1}\left(X_{t}\right)+\beta_{2}\left(Z_{t}\right)+\varepsilon_{t}
\end{aligned}
$$

where $X_{t}$ is a vector of explanatory variables for fundamental information such as price change (PC), total shares traded (TST), total value traded (TVT), issued shares (IS), market capitalisation (M_CAP), dividend per share (DPS), dividend yield (DY), earning per share (EPS), price per earning (PE). $Z_{t}$ is a vector that captures the macroeconomics variables employed, namely, inflation (INFL) and gross domestic product (GDP) and $\varepsilon_{i t}$ is the error term. When $R_{m, t}$ and $R_{m, t}^{2}$ are statistically insignificant and non-linear both fundamental information and macroeconomic fundamental variables, then the variation in $C S A D_{t}$ is a result of fundamental information instead of herding. Herding is tested under six (6) sectors from the initial nine (9) sectors. A drop of three (3) sectors from the analysis is as a result of missing or insufficient observations.

The study further estimates the impact of herding on stock returns. This is to help measure the impact of herd behavior on stock returns. The equation is stated as:

$$
S T R_{i t}=\beta_{0}+\beta_{i} X_{i t}+\delta_{i} Z_{i t}+\left|R_{m, t}\right|+R_{m, t}^{2}+\operatorname{CSSD}_{i t}+C S A D_{i t}+k_{i}+\varepsilon_{i t}
$$

where $S T R_{i t}$ represents stock returns, $X_{t}$ is a vector of explanatory variables for fundamental information, $Z_{t}$ is a vector that captures the macroeconomics variables employed, $\left|R_{m, t}\right|$ is the absolute market returns and $R_{m, t}^{2}$ is the quadratic form of the absolute market returns. $i$ and $t$ index firms and time periods respectively; $k_{i}$ is firm heterogeneity and $\varepsilon_{i t}$ represents a white noise error term. 


\section{DISCUSSIONS OF RESULTS}

\section{Descriptive Statistics}

Table 3 presents the summary statistics of the study. When herding measures show a minimum value of zero, it suggests that all individual stock returns move together with the market. Notwithstanding, when individual stock returns deviate from the market, the value increases. Table 3 reports lower values for $C S S D_{t}$ and $C S A D_{t}$. Interestingly, daily returns of GSE share reveal high mean values and high standard deviations. This result parallels the empirical works of Chang et al. (2000) and Tan et al. (2008) who concur that well efficient markets have higher mean values of market returns and higher volatility. Again, the positive mean for both market return variables could be as a result of GSE performance over the period under review. With regards to the control variables, the results are not different. 


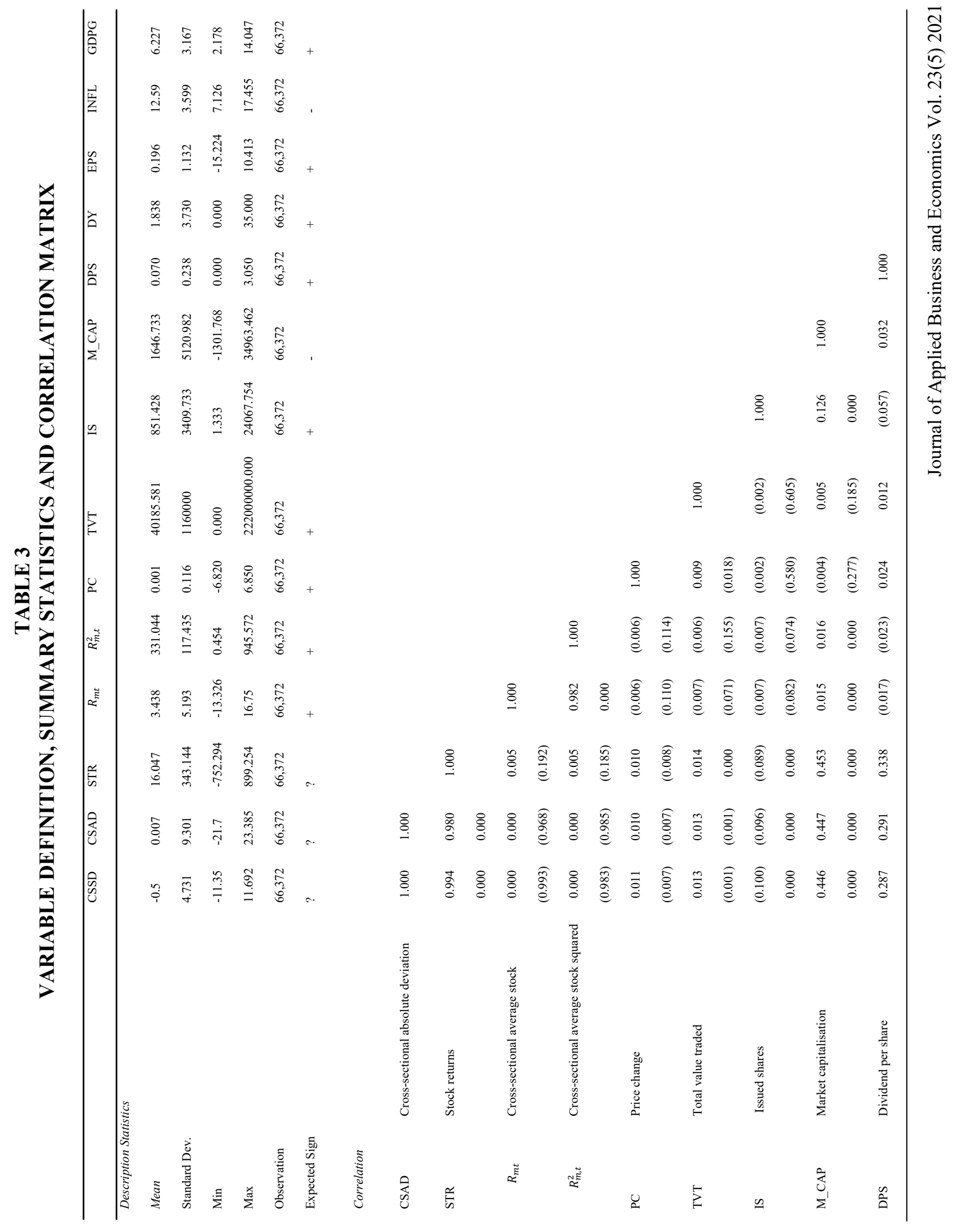




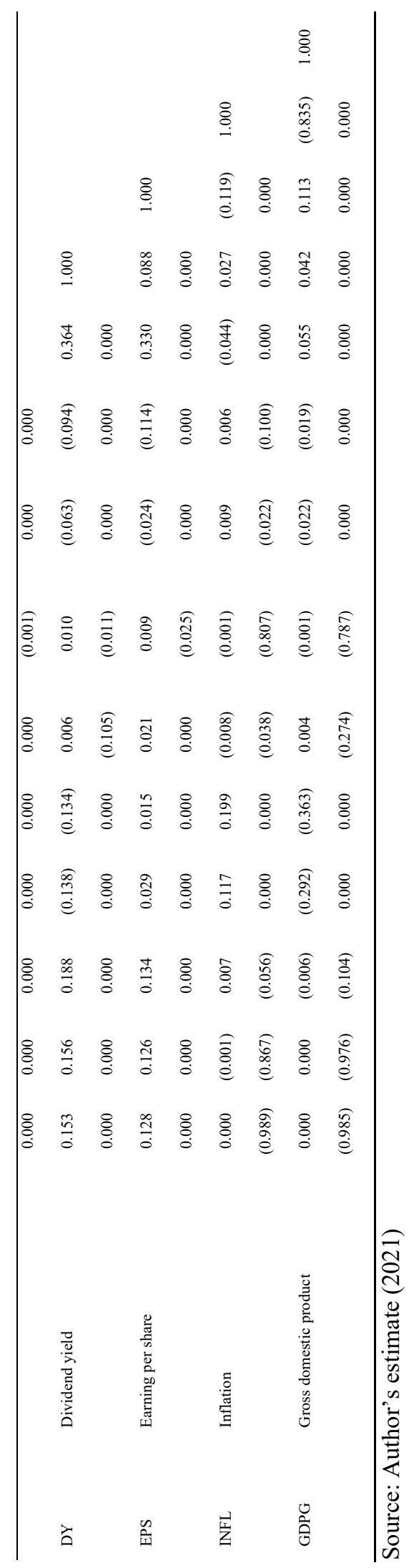




\section{Estimates for Extreme Market Movements Using CSSD and CSAD}

Herding behaviours under market stress are reported in Table 4. The relevance of this estimation is to find out if the traditional asset pricing model is validated or otherwise during periods of extreme market movements. At 1 and 5 percent significant levels, using CSSD at 5 percent extreme upper tail of the returns distribution, model 1 yields a positive and significant coefficient suggesting divergence of individual market returns from the aggregate market portfolio returns. This result confirms an absence of herding behaviour supporting the assumption of rational asset pricing. At 1 percent extreme upper tail of the returns distribution, model 2 produces a positive and significant coefficient supporting an absence of herding behaviour. Similar results are produced when CASD is used in both models 3 and 4. Stated differently, regardless of methods used for dispersion, market returns exhibit the same results (Christie \& Huang, 1995; Gleason et al., 2004). Specifically, at extreme market movements, GSE does not observe herding behaviour.

TABLE 4

\section{HERDING UNDER EXTREME MARKET MOVEMENT}

\begin{tabular}{|c|c|c|c|c|}
\hline Variables & $\begin{array}{c}\text { (Model 1) } \\
\text { CSSD }\end{array}$ & $\begin{array}{c}\text { (Model 2) } \\
\text { CSSD }\end{array}$ & $\begin{array}{c}\text { (Model 3) } \\
\text { CASD }\end{array}$ & $\begin{array}{c}\text { (Model 4) } \\
\text { CASD }\end{array}$ \\
\hline & $\begin{array}{c}-0.0401 \\
(0.0213)\end{array}$ & & $\begin{array}{l}-0.0942 \\
(0.0485)\end{array}$ & \\
\hline & $\begin{array}{c}0.1359 * * * \\
(0.0256)\end{array}$ & & $\begin{array}{c}0.2553 * * * \\
(0.0581)\end{array}$ & \\
\hline & & $\begin{array}{l}-0.0415 \\
(0.0405)\end{array}$ & & $\begin{array}{l}-0.0961 \\
(0.0922)\end{array}$ \\
\hline & & $\begin{array}{c}0.1208 * * * \\
(0.0398)\end{array}$ & & $\begin{array}{c}0.2282 * * \\
(0.0905)\end{array}$ \\
\hline Constant & $\begin{array}{c}-0.5033 * * * \\
(0.0058)\end{array}$ & $\begin{array}{c}-0.5012 * * * \\
(0.0055)\end{array}$ & $\begin{array}{c}0.0011 \\
(0.0131)\end{array}$ & $\begin{array}{c}0.0040 \\
(0.0126)\end{array}$ \\
\hline Observations & 66,372 & 66,372 & 66,372 & 66,372 \\
\hline R-squared & 0.0005 & 0.0002 & 0.0004 & 0.0001 \\
\hline Adjusted R-sq & 0.0085 & 0.0043 & 0.0022 & 0.0047 \\
\hline Number of Equity & 38 & 38 & 38 & 38 \\
\hline F statistic & 16.56 & 5.192 & 12.08 & 3.771 \\
\hline
\end{tabular}

Standard errors in parentheses $* * * \mathrm{p}<0.01, * * \mathrm{p}<0.05$

Source: Author's estimate (2021).

\section{Estimation of Non-Linearity, Bull and Bear Conditions Using CSSD and CSAD}

Table 5 presents the results for non-linearity, bull and bear conditions using CSSD and CSAD. The study introduces a quadratic term to estimate the probability of non-linearity to variation in dispersion. In models 1 and 2, while $y_{1}$ coefficients are negative and statistically significant, $\gamma_{2}$ coefficients are positive and significant. This result indicates that at low levels, the market participants herd but at higher levels, there is the absence of herding behavior (Chang et al., 2000). The result also finds support in the empirical study of Demirer et al. (2007) who conclude that dispersion in African markets follows a parabolic path. Model 3 to model 6 in Table 5, absolute returns are employed to examine evidence of herding behavior during bull and bear conditions. While models 3 and 4 capture the up market returns, models 5 and 6 report the down market returns. In bullish market conditions, while $\gamma_{1}$ coefficients are positive and statistically 
significant, $\gamma_{2}$ coefficients are negative and significant. This implies that at lower levels herding behavior does not exist. Market participants act in unison only at high levels. A reverse result is the case when bear market conditions are examined.

TABLE 5

FIXED EFFECT ESTIMATION OF NON-LINEARITY USING CSSD AND CSAD

\begin{tabular}{|c|c|c|c|c|c|c|}
\hline \multirow[b]{2}{*}{ Variables } & \multirow{2}{*}{$\begin{array}{l}\text { (Model 1) } \\
\text { Non linearity } \\
\text { CSSD } \\
\end{array}$} & \multirow{2}{*}{$\begin{array}{c}\text { (Model 2) } \\
\text { Non linearity } \\
\text { CASD }\end{array}$} & \multicolumn{2}{|c|}{$\begin{array}{c}\text { (Model 3) } \quad \text { (Model 4) } \\
\text { Bull market conditions } \\
R_{m, t}>0\end{array}$} & \multicolumn{2}{|c|}{$\begin{array}{c}\text { (Model 5) } \quad(\text { Model 6) } \\
\text { Bear market conditions } \\
R_{m, t}<0\end{array}$} \\
\hline & & & CSSD & CASD & CSSD & CASD \\
\hline$R_{m, t}$ & $\begin{array}{c}-0.0636^{* * *} \\
(0.0056)\end{array}$ & $\begin{array}{c}-0.1216^{* * *} \\
(0.0127)\end{array}$ & $\begin{array}{c}0.1998 * * * \\
(0.0506)\end{array}$ & $\begin{array}{c}0.4159 * * * \\
(0.1175)\end{array}$ & $\begin{array}{l}-0.0115^{*} \\
(0.0059)\end{array}$ & $\begin{array}{l}-0.0229 * \\
(0.0119)\end{array}$ \\
\hline$R_{m, t}^{2}$ & $\begin{array}{c}0.0031^{* * *} \\
(0.0002)\end{array}$ & $\begin{array}{c}0.0061^{* * *} \\
(0.0006)\end{array}$ & $\begin{array}{c}-0.0034 * * * \\
(0.0013)\end{array}$ & $\begin{array}{c}-0.0073^{* *} \\
(0.0030)\end{array}$ & $\begin{array}{c}0.0031 * * * \\
(0.0005)\end{array}$ & $\begin{array}{c}0.0061 * * * \\
(0.0011)\end{array}$ \\
\hline Constant & $\begin{array}{c}-0.4325 * * * \\
(0.0236)\end{array}$ & $\begin{array}{c}0.1181 * * \\
(0.0536)\end{array}$ & $\begin{array}{c}-3.0668 * * * \\
(0.5004)\end{array}$ & $\begin{array}{c}-5.2535^{* * *} \\
(1.1621)\end{array}$ & $\begin{array}{c}-0.4934 * * * \\
(0.0110)\end{array}$ & $\begin{array}{c}0.0129 \\
(0.0221)\end{array}$ \\
\hline Observations & 66,372 & 66,372 & 59,689 & 59,689 & 6,546 & 6,546 \\
\hline R-squared & 0.0030 & 0.0022 & 0.0037 & 0.0026 & 0.0095 & 0.0094 \\
\hline Adjusted R-sq & 0.0024 & 0.0016 & 0.0031 & 0.002 & 0.0037 & 0.0036 \\
\hline Number of Equity & 38 & 38 & 38 & 38 & 37 & 37 \\
\hline F statistic & 98.54 & 73.08 & 111.5 & 78.77 & 31.06 & 30.92 \\
\hline
\end{tabular}

\section{Estimation of Herding Under Different Sectors Using CSSD and CSAD}

Table 6 reports herding behavior under different sectors using CSSD. Model 1 which considers all the combined sectors, shows a herding behavior only at the lower levels. At higher levels, however, market participants do not herd. When equities are decomposed into sectors, varying and interesting herding results are produced. Model 1 and 6 confirm the traditional asset pricing model only at the higher levels but invalidate the traditional asset pricing model at lower levels. In model 3, 4, 5 and 7, $\gamma_{1}$ 's are significantly negative indicating that at lower levels, individual sectors exhibit the presence of herding. At higher levels, however, results are insignificant except Model 7 which exhibits an absence of herding behavior. The exhibition of herding behavior among these sectors could suggest that these equities have existed since the post-colonial era, hence information among investors are similar. Table 7 reports herding behavior when CASD measure is used. Stock market participants exhibit herding behavior at lower levels across all sectors combined and absence of herding at higher levels. While individual sectors show herding behaviors at lower levels except for industry sectors, Model 2, 4, 5 and 7 failed to show herding behavior. 


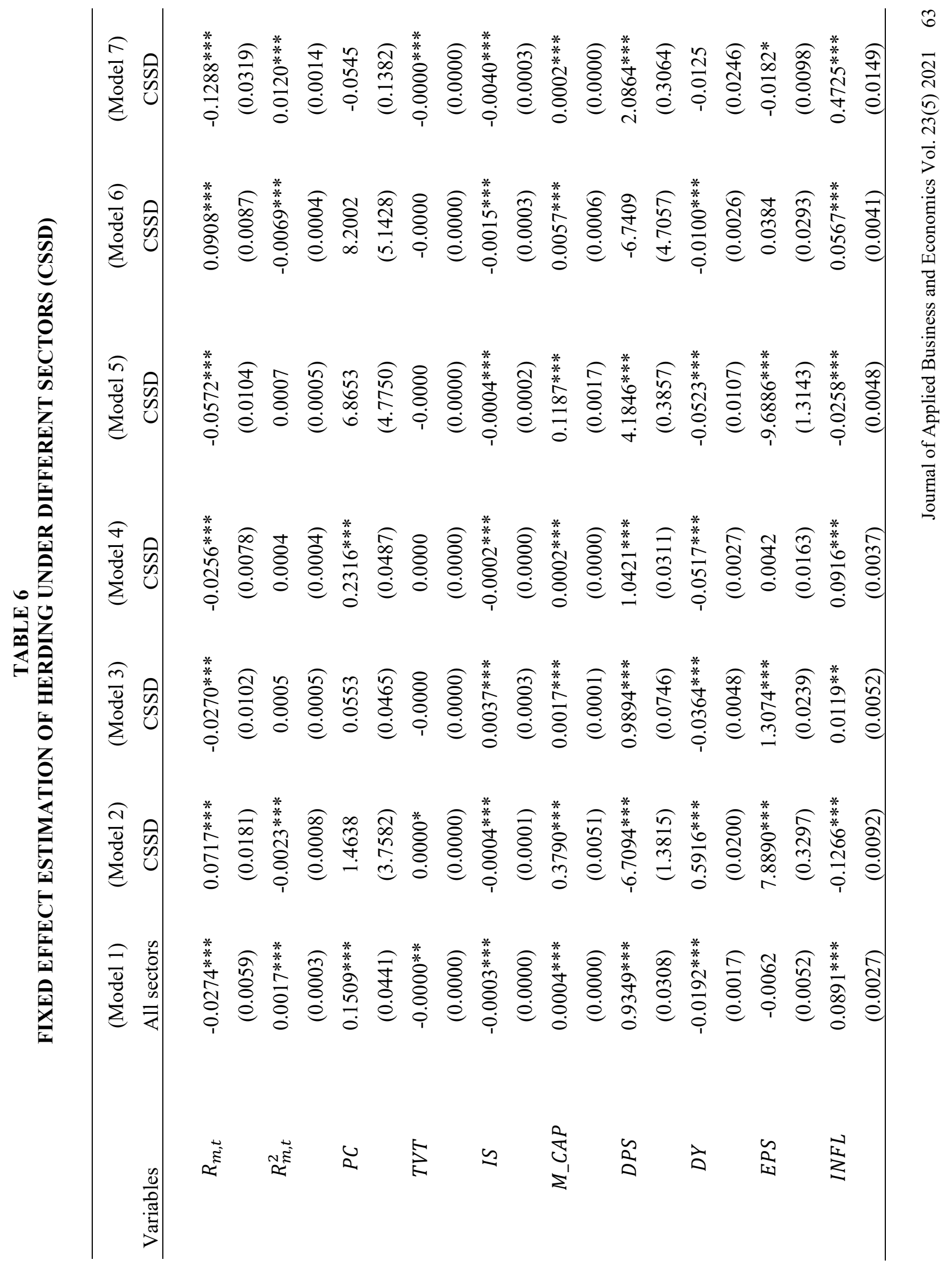




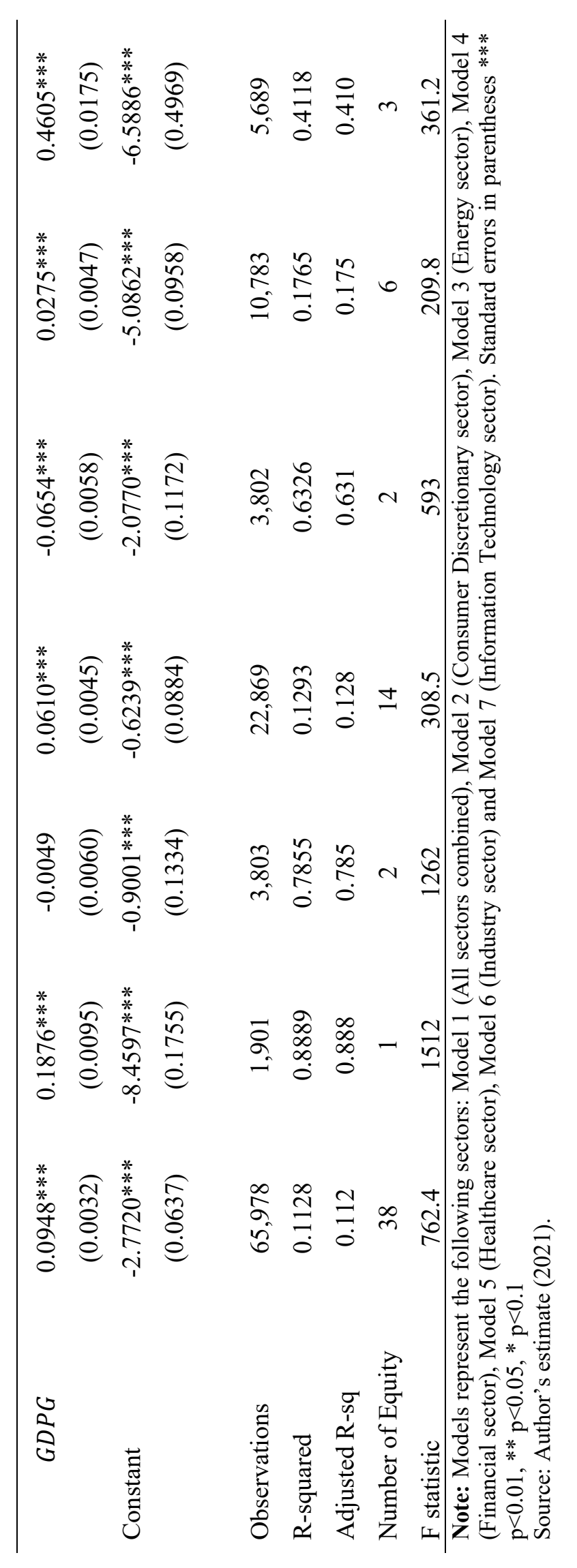




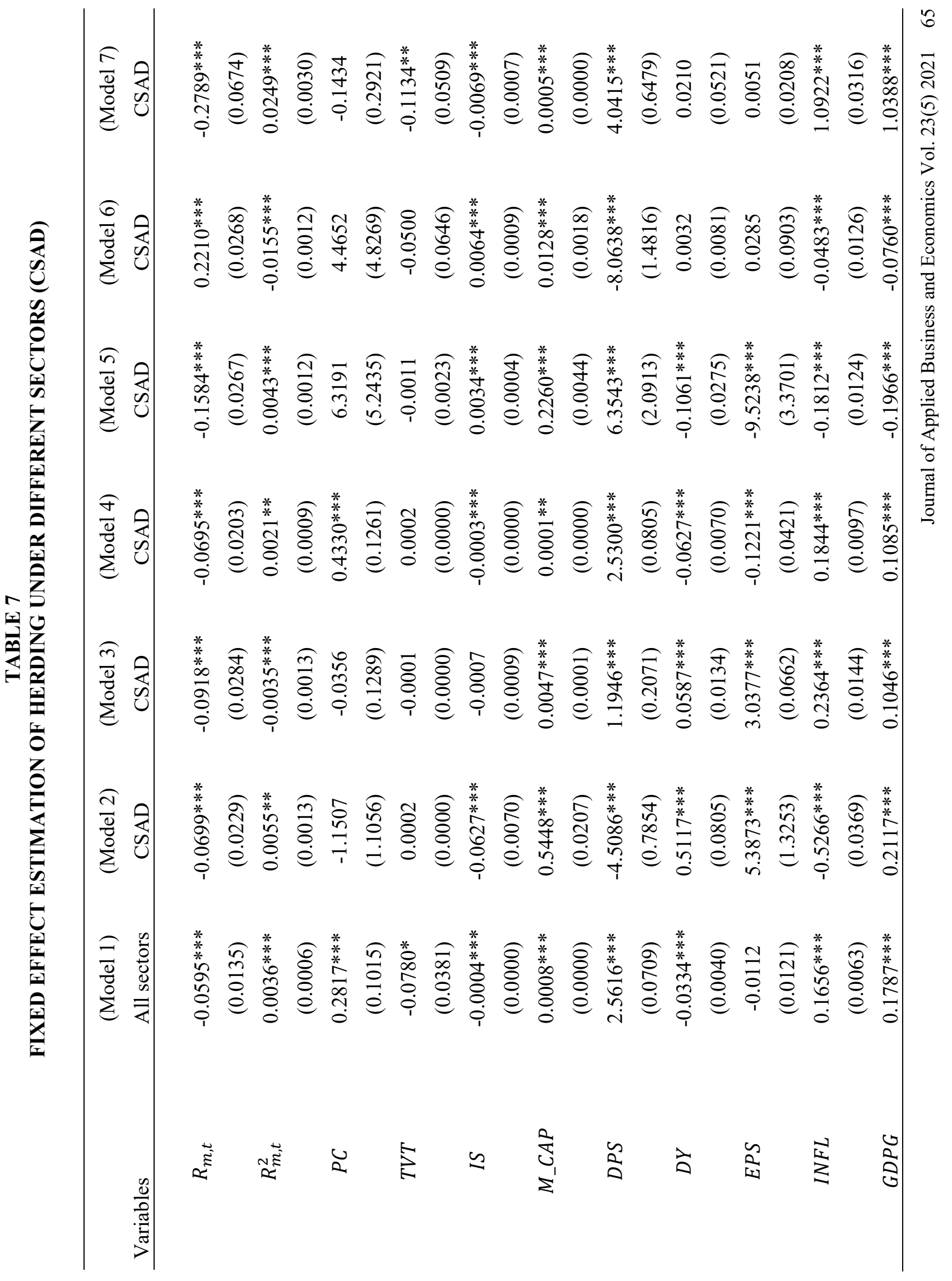




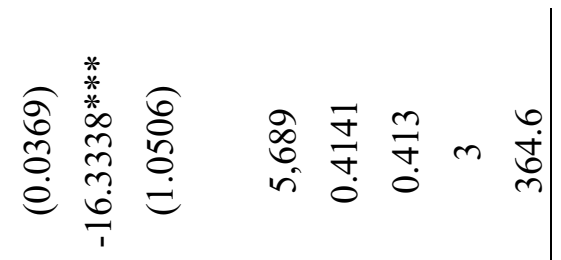

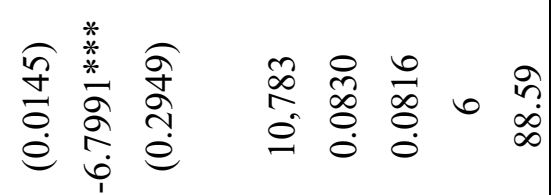

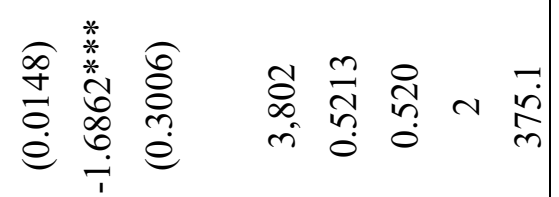

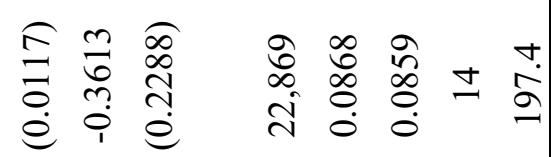

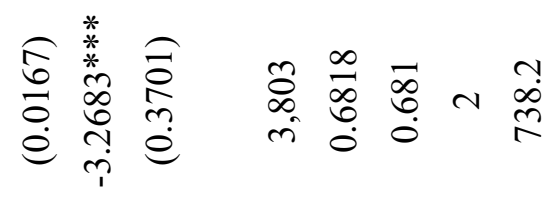

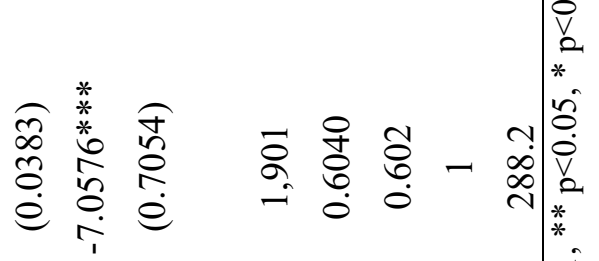

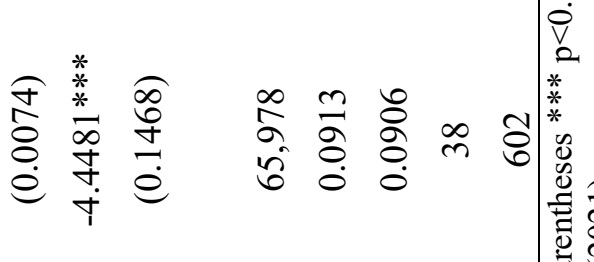

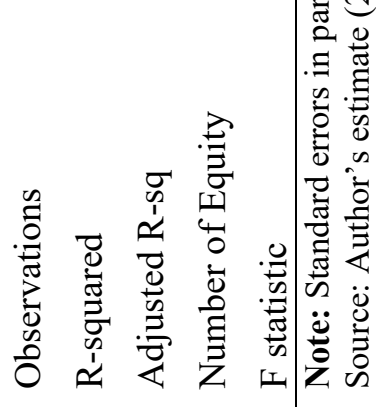




\section{Estimation of Herding Impact on Stock Returns Using CSSD and CSAD}

Earlier results from this study suggest an absence of herding. However, varied herding behaviours results are produced when data is decomposed into different sectors. Therefore, the need to investigate the relationship between herding and stock returns under different sectors is essential. The relevance of estimating this relationship is premised on the fact that stock prices are destabilized or stabilized when a group of investors herd together to buy or sell equity. Related studies (Hirshleifer et al., 1994; Sias (2004), suggest that the market will observe price continuity if herding is information-based. In contrast, stock markets observe a price reversal if the herding is necessitated by behavioral factors (Scharfstein \& Stein, 1990). In Model 1 which combines all sectors as shown in Table 8, herding has a positive impact on stock returns at 1 percent significance level. This suggests that the imitative behaviour of investors in capital markets positively affects stock returns. The result supports the dynamic and asymmetric herding behaviour of US equity fund managers in the stock market investigated by Fang et al. (2017). The study further tested different market stresses that potentially affect investor behaviour. While at lower levels herding impacts positively on stock returns, the opposite is the case at higher levels. When fundamental information and macroeconomic fundamental characteristics are examined, price change (PC), market capitalization (M_CAP), earning per share (EPS) and gross domestic product (GDP) impact positively on stock returns. Issued shares (IS), dividend per share (DPS), dividend yield (DY) and inflation (INFL) influence stock returns negatively. When the daily data is decomposed into six (6) sectors, surprisingly herding impacts positively on stock returns at 1 percent significance level. When CSAD is introduced as captured in Table 9 , results are not different. Specifically, herding positively affects stock returns. 


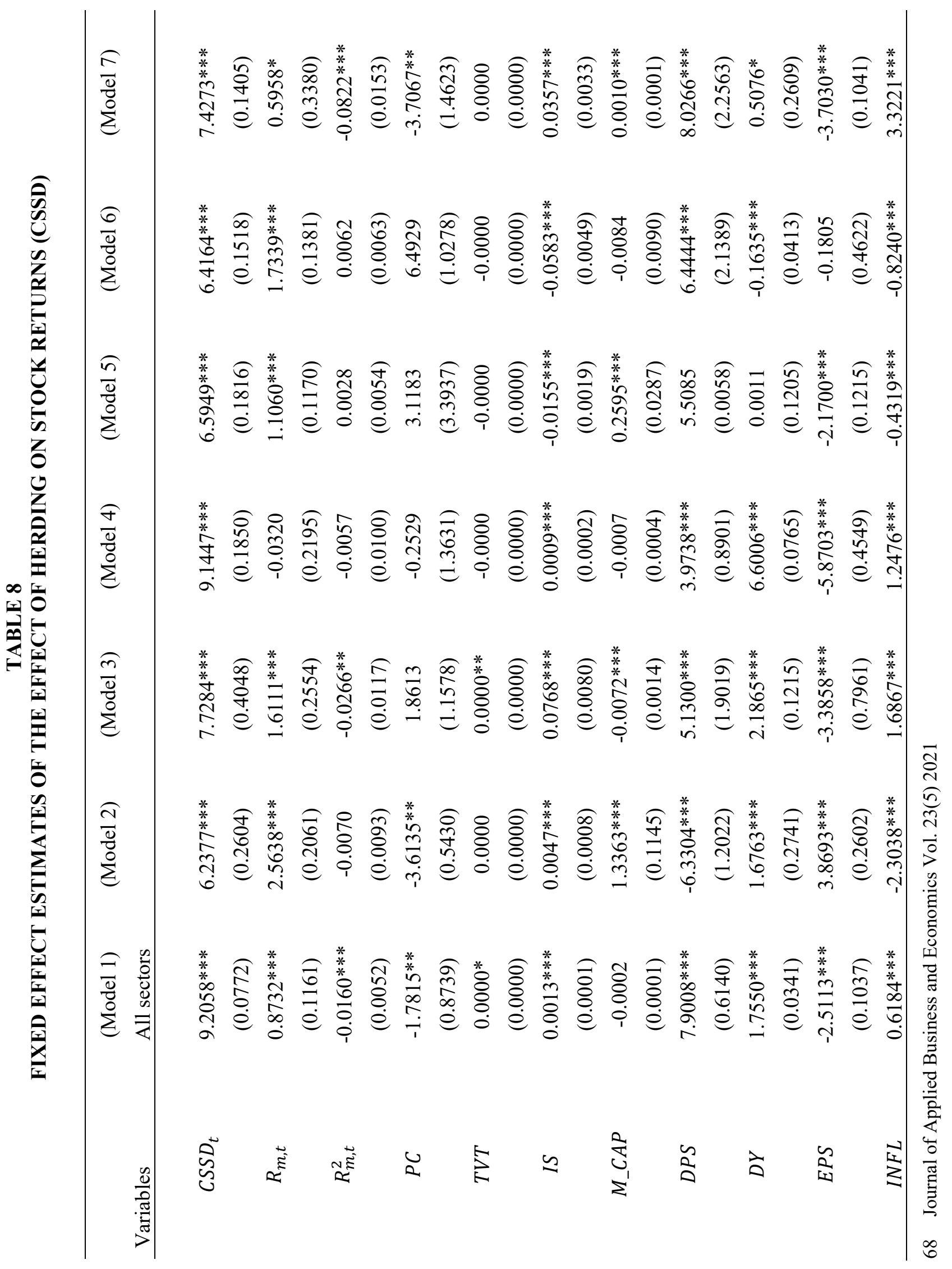




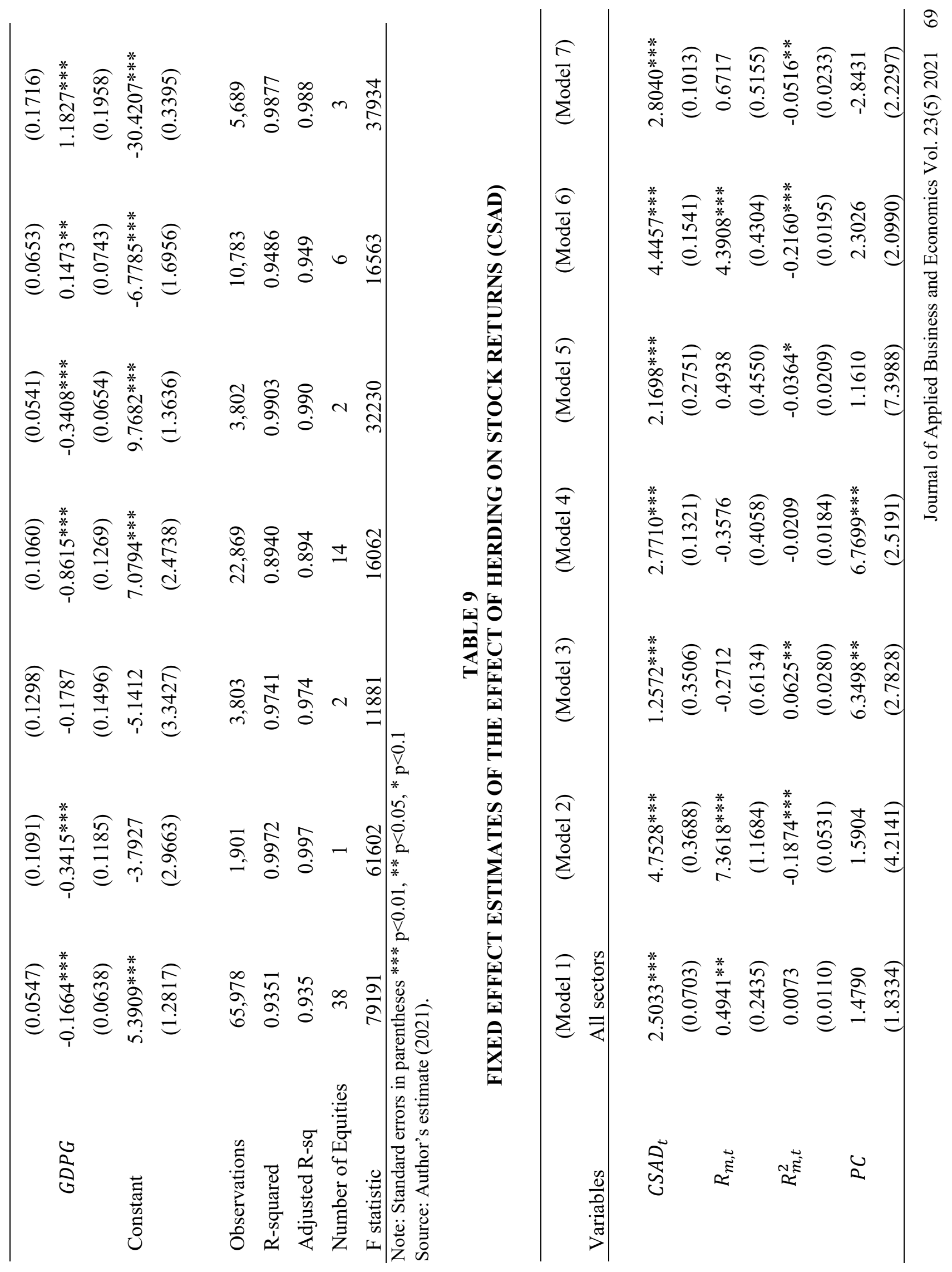




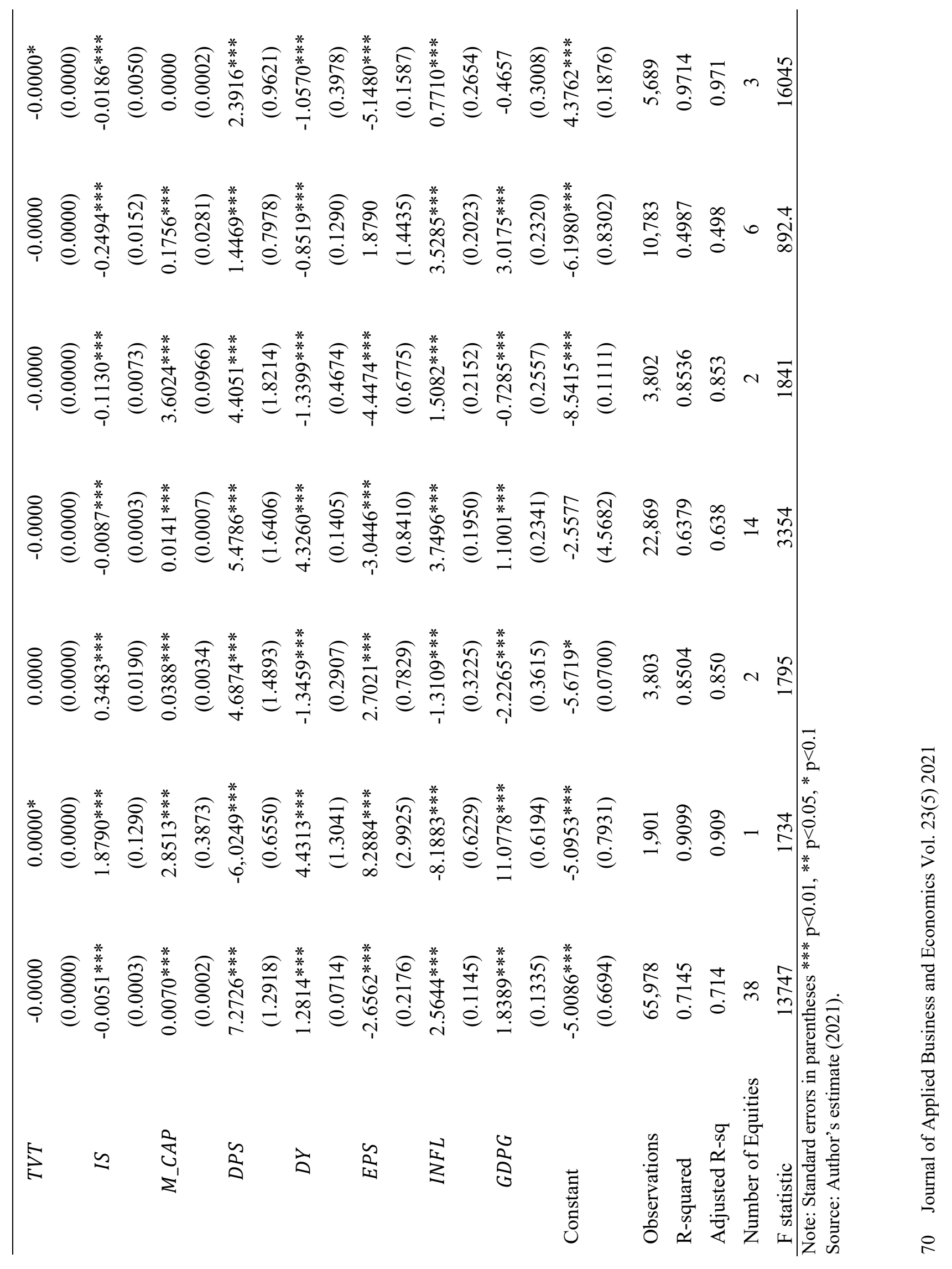




\section{CONCLUSION AND IMPLICATIONS}

The present study examines the existence of herding behavior in Ghana stock markets. The study employs the fixed effect model for all our estimations. The analysis presents the following results: First, the study indicates no evidence of herding behaviour for the period under examination. Periods of extreme price movements, stock return dispersions increase rather than decrease, yielding support against herding behaviour. This result does not only support the empirical works of Christie \& Huang (1995), Chang et al. (2000) and Gleason et al. (2004) but also validates the assumption of the rational asset pricing model. In extreme market movements, the Ghana stock market is efficient. Second, results for non-linearity in examining variation in dispersion show that at low levels, the market participants herd but at higher levels, there is an absence of herding behavior. The result also finds support in the empirical study of Demirer et al. (2007) who conclude that dispersion in African markets follows a parabolic path. In bull market conditions, while at lower levels herding behavior does not exist, market participants act in unison only at high levels. A reverse result is the case when bear market conditions are examined. In addition, when equities are decomposed into sectors, varying and interesting herding results are produced. Both consumer discretionary and industry sectors confirm the traditional asset pricing model only at the higher levels but invalidate the traditional asset pricing model at lower levels. Apart from the two sectors, the rest of the sectors are significantly negative indicating that at lower levels, individual sectors exhibit the presence of herding. At higher levels, however, results are insignificant except the information technology sector which exhibits an absence of herding behaviour. The exhibition of herding behaviour among these four (4) sectors could suggest that these equities have existed since the post-colonial era, hence information among investors are similar. Finally, the relationship between herding and stock returns under different sectors is examined. When all the sectors are combined, results indicate that at lower levels herding impacts positively on stock returns, the opposite is the case at higher levels. This result suggests that the imitative behavior of investors in capital markets positively affects stock returns. The result supports the dynamic and asymmetric herding behavior of US equity fund managers in the stock market investigated by Fang et al. (2017). When the daily data is decomposed into six (6) sectors, surprisingly, herding impacts positively on stock returns at 1 percent significance level.

From the findings of the study, the authors recommend the following strategic managerial and policy implications:

\section{Managerial Implications}

First, the absence of herding behaviour in Ghana stock market may be explained by the fact that, during panic periods, investors do not throw away their rationality to engage in collective herd behaviour. Management should be aware that in terms of investment decisions, individual investors in a group decide individually without centralized direction. This further suggests that Ghanaian stock investors are more cautious and analytical in their investment decisions. Second, the validation of rational asset pricing models in extreme market movements could possibly suggest that Ghana stock market is efficient. Third, the sectoral analysis provides further directions for management. Results from the study indicate that four (4) sectors (Energy, Financial, Healthcare and Information Technology) throw away their rationality to engage in a collective herd behavior during the period under examination. This adds to the call for management to investigate further what could contribute to this. A casual answer provided by the authors could be that investors are predominantly domestic dominant shareholders and therefore could benefit from insider information or just follow the herd. In addition, in bull market conditions where share prices are rising encouraging buying, the result shows that herding behavior does not exist at lower levels. Rather market participants act in unison only at high levels. Management should, therefore, be concerned about the timing of anti-herding policies. Finally, when the daily data is decomposed into six (6) sectors, interestingly, herding impacts positively on stock returns in all sectors. This finding is relevant for managers of these equities as far as trading at GSE is concerned. This is because the action to herd together to buy or sell equity by a group of investors can potentially destabilize or stabilize the stock market. 


\section{Policy Implications}

Considering the value relevance of the Ghana stock exchange and its contributions to the economy over the period, pro-market-based policies that enhance the smooth operations of the market should be pursued by policymakers. The validation of the rational asset pricing model in extreme market movements could possibly by this study suggest that Ghana stock market is efficient. Following this result, policymakers and governments should institute measures to consolidate the gains and protect these equities against an onslaught of foreign influences.

\section{Limitation and Future Research}

Findings from the study are based on data captured after the global financial meltdown constituting 66,372 observations. Nevertheless, this does not invalidate the general outcome of the study. Examination of herding behaviour of Ghana stock market participants before the global financial meltdown surely deserves attention in future research.

\section{REFERENCES}

Balcilar, M., Demirer. R., \& Hammoudeh, S. (2013). Investor herds and regime-switching: Evidence from Gulf Arab stock markets. Journal of International Financial Markets, Institutions and Money, 23(1), 295-321.

Banerjee, A. (1992). A simple model of herd behavior. Quarterly Journal of Economics, 107(3), 797-817.

Bhaduri, S.N., \& Mahapatra, S.D. (2013). Applying an alternative test of herding behavior: A case study of the Indian stock market. Journal of Asian Economics, 25(1), 43-52.

Blasco, N., Corredor, P., \& Ferreruela, S. (2012). Does herding affect volatility? Implications for the Spanish stock market. Quantitative Finance, 12(2), 311-327.

Boadi, I. (2018). The predictability of Ghana stock returns: implications of fundamental information analysis. International Journal of Business and Globalisation, 20(1), 50-70.

Cajueiro, D.O., \& Tabak, B.M. (2009). Multifractality and herding behavior in the Japanese stock market. Chaos, Solitons \& Fractals, 40(1), 497-504.

Chang, E., Cheng, J., \& Khorana, A. (2000). An examination of herd behavior in equity markets: An international perspective. Journal of Banking \& Finance, 24(10), 1651-1679.

Chari, V.V., \& Kehoe, P. (2004). Financial crises as herds: Overturning the critiques. Journal of Economic Theory, 119, 129-150.

Chiang, T.C., Li, J., \& Tan, L. (2010). Empirical investigation of herding behavior in Chinese stock markets: Evidence from quantile regression analysis. Global Finance Journal, 21(1), 111-124.

Christie, W., \& Huang, R. (1995). Following the pied piper: Do individual returns herd around the market? Financial Analysts Journal, 51(4), 31-37.

Demirer, R., \& Kutan, A.M. (2006). Does herding behavior exist in Chinese stock markets? Journal of International Financial Markets, Institutions and Money, 16(2), 123-142.

Demirer, R., Gubo, D., \& Kutan, A.M. (2007). An analysis of cross-country herd behavior in stock markets: A regional perspective. Journal of International Financial Markets, Institutions and Money, 3, 123-142.

Economou, F., Kostakis, A., \& Philippas, N. (2011). Cross-country effects in herding behaviour: Evidence from four south European markets. Journal of International Financial Markets, Institutions and Money, 21(3), 443-460.

Fama, E. (1990). Stock returns, expected returns, and real activity. Journal of Finance, 45(4), 1089-1108.

Fanga, H., Shenb, C.H., \& Yen-Hsien Leec, Y.H. (2017). The dynamic and asymmetric herding behavior of US equity fund managers in the stock market. International Review of Economics and Finance, 49(1), 353-369.

Ferruz, A., \& LuisVargas Magallón, M. (2007). Análisis de las capacidades de sincronización con el mercado y selección de valores de los gestores de fondos de inversión españoles en condiciones económicas variables. El Trimestre Económico, 74(3), 663-683. 
Froot, K., Scharfstein, D., \& Stein, J. (1992). Herd on the street: Informational inefficiencies in a market with short-term speculation. Journal of Finance, 47, 1461-1484.

Galariotis, E., Rong, W., \& Spyrou, S. (2015). Herding on fundamental information: A comparative study. Journal of Banking and Finance, 50(1), 589-598.

Gleason, K., Mathur, I., \& Peterson, M. (2004). Analysis of intraday herding behavior among the sector ETFs. Journal of Empirical Finance, 11(5), 681-694.

Hirshleifer, D., Subrahmanyam, A., \& Titman, S. (1994). Security Analysis and Trading Patterns When Some Investors Receive Information Before Others. Journal of Finance, 49(5), 1665-1698.

International Monetary Fund. (2019). Regional economic outlook. Retrieved June 20, 2019, from https://www.imf.org/en/Countries/ResRep/GHA

Kumar, S., \& Goyal, N. (2016). Evidence on rationality and behavioural biases in investment decision making. Qualitative Research in Financial Markets, 8(4), 270-287. https://doi.org/10.1108/QRFM-05-2016-0016

Lin, A.Y., \& Swanson, P.E. (2003). The behavior and performance of foreign investors in emerging equity markets: Evidence from Taiwan. International Review of Finance, 23(1), 4189-4210.

Mobarek, A., Mollah, S., \& Keasey, K. (2014). A cross-country analysis of herd behavior in Europe. Journal of International Financial Markets, Institutions \& Money, 32, 107-127.

Olsen, R.A. (1996). Implications of herding behavior for earnings estimation, risk assessment, and stock returns. Financial Analysts Journal, 52(4), 37-41.

Ornelas, J., \& Alemanni, B. (2008). Herding behavior by equity foreign investors on emerging markets. (Working Paper No. 125). Banco Central do Brasil, Central Bank of Brazil, Brasilia, Brazil. Prosad,

Philippas, N., Economou, F., Babalos, V., \& Kostakis, A. (2013). Herding behavior in REITs: Novel tests and the role of financial crisis. International Review of Financial Analysis, 29(1), 166-174.

Sarkar, A.H., \& Ahsan, A.F. (2013). Herding in Dhaka stock exchange. Journal of Applied Business and Economics, 14(2), 11-19.

Satish, K., \& Nisha, G. (2016). Evidence on rationality and behavioral biases in investment decision making. Qualitative Research in Financial Markets, 8(4), 270-287. https://doi.org/10.1108/QRFM-05-2016-0016

Scharfstein, D., \& Stein, J. (1990). Herd behavior and investment. American Economic Review, 80(1), 465-479.

Sias, R.W. (2004). Institutional herding. The Review of Financial Studies, 17(1), 165-2006.

Tan, L., Chiang, T.C., Mason, J.R., \& Nelling, E. (2008). Herding behavior in Chinese stock markets: An examination of A and B shares. Pacific-Basin Finance Journal, 16(1), 61-77.

The Institute for Economics and Peace. (2019). Global peace index. Retrieved June 20, 2019, from http://visionof_humanity.org/app/uploads/2019/06/GPI-2019-web003.pdf

Vo, X.V., \& Anh Phan, D.B. (2017). Further evidence on the herd behavior in Vietnam stock Market. Journal of Behavioral and Experimental Finance, 13(1), 33-41.

Zhou, J., \& Anderson, R.I. (2011). An empirical investigation of herding behavior in the U.S. REIT market. The Journal of Real Estate Finance and Economics, 1(47), 1-26.

Zuee J., \& Arshad, H. (2015). An examination of herding behavior in Pakistani stock Market. International Journal of Emerging Markets, 10(3), 474-490. https://doi.org/10.1108/IJoEM-07-2011-0064 